\title{
Serangan Tourism Village Management Strategy for Achieving Quality Tourism Destinations
}

\author{
I Gede Putra Nugraha ${ }^{1, *}$ Putu Indah Rahmawati ${ }^{1}$ Ni Luh Henny Andayani ${ }^{1}$ \\ ${ }^{1}$ Department of Management, Universitas Pendidikan Ganesha, Singaraja, Indonesia \\ ${ }^{*}$ Corresponding author. Email: dedenugraha@ymail.com
}

\begin{abstract}
This article discusses the tourism village management strategy carried out by the Serangan Village Tourism Awareness Group in collaboration with the Denpasar City Government with local communities in developing quality tourist destinations in Serangan Village. The method used is observation and interviews with informants, namely the secretary of Serangan Pokdarwis, The Head of Serangan Village and Head of BUMDA Serangan. It is known that in the implementation of the development of tourist destinations in Serangan, the government and tourism awareness groups in Serangan Village take a role as a facilitator in preparing tourism facilities and infrastructure in Serangan and also as a dynamisator which provides skills training and governance of tourist villages so that the management of Serangan tourist destinations becomes more professional.
\end{abstract}

Keywords: Management, Tourism destination, Tourism village, Tourism management.

\section{INTRODUCTION}

There are three essential components that determine the sustainability of tourist destination development in the tourism destination development paradigm: culture, environment, and economy. These three primary components are interrelated and work together to generate high-quality tourist destinations in order to meet the aims of long-term tourism development [1].

To obtain great tourist destinations, these destinations must, of course, be professionally managed and have benefits that attract travellers in competition with other tourist destinations around the world. The form of competitiveness can be seen from the advantages of tourist attractions, social culture, and natural environment. Furthermore, in the process of developing community-based tourism villages, synergistic partnerships and cooperation between the government, local communities, and the commercial sector are required [2]. The goal of building highquality, long-term tourist attractions will be met in this way.

With the provision of Mayor's Decree No. $188.45 / 472 / \mathrm{HK} / 2015$ about the construction of a tourist village in Denpasar City, Serangan Village has been a tourist village since 2015. With the designation of Serangan Village as a tourist village, the administration of tourism sites including the government, local communities, and the business sector becomes a very intriguing topic to research. This Serangan Village has the potential to become a tourist destination due to its location. Serangan Village is conveniently located between the golden triangle of Bali tourism (Sanur, Nusadua, and Kuta), making it accessible to both local and international visitors. Figure 1 depicts the entrance of Serangan Village. However, polemics about the connection between the government, local populations, and investors frequently arise during the development process. This complicates the process of establishing a tourist resort in Serangan Village.

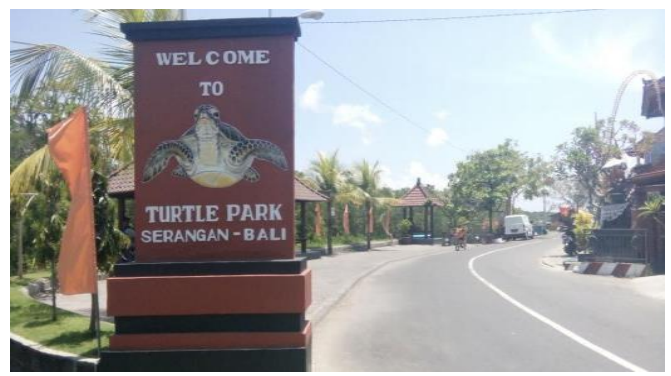

Figure 1 Serangan Village entrance

Based on these issues, a study was conducted under the title of Serangan Tourism Village Management Strategy in order to create high-quality tourist 
attractions that were thought to be effective in resolving issues. This research attempts to determine Serangan Tourism Village's management approach for creating high-quality tourism destinations.

\section{LITERATURE REVIEW}

According to reference [3] found that the development of tourist attractions in Jatiluwih Village directly absorbs labor from the local community, preserves the environment, and empowers local communities to participate in the management of tourist villages in Jatiluwih in his study "Tourism Development and Community Involvement in Jatiluwih Tourism Village." However, it was discovered that traditional Saka Roras structures were being commodified and that there were conflicts of interest.

In his research in Penglipuran Bangli Village, [4] discovered that the arrival of the tourism industry into the Penglipuran Traditional Village resulted in a change in the economic structure due to numerous economic activities that support the tourism sector. Employment options are being expanded, community income is being increased, and traditional communities are being encouraged to retain culture, particularly in the design of existing architecture in the local village.

In research done in Jatiluwih Village, [5] discovered that the Jatiluwih Village Service appears to have a more prominent role in administering tourism villages in the area. This makes the traditional village not get the maximum role in managing the tourist village. This, of course, differs from the original idea for the development of a tourist village in Jatiluwih, which intended for the tourist village to be administered by a traditional village.

The participation and empowerment of local populations as one of the supporting aspects in development initiatives cannot be separated from the development of tourist villages. The planning stage, implementation stage, management stage, and oversight stage are all parts of local community empowerment in the development of tourist villages [6].

Tourist destination management must be able to involve local people and deliver benefits to them. Furthermore, the development of tourist destinations must not harm the local community's socio-cultural values, and the carrying capacity of these tourist sites must not surpass the capacity of local tourist destinations [7].

According to [8], tourist management must address a number of themes, including sustainable tourism development, tourism economic development, and environmental sustainability. The purpose of sustainable tourism development is to manage tourist locations that pay attention to carrying capacity and environmental sustainability.

\section{METHOD}

Primary data for this study came from interviews with I Wayan Karma, S.Ip, the Serangan Village Head, I Wayan Sutarja, the Serangan Pokdarwis secretary, and I Nyoman Turut, the Serangan BUMDA chairman. In the technical analysis of this research data, the data collected from the informants was described qualitatively. The Serangan Village Profile Book is also used for secondary data.

\section{RESULTS \& DISCUSSION}

\subsection{Serangan Tourism's Potential and Attraction}

Serangan Village is a 481-hectare village in the South Denpasar District. It is separated into two regions, one belonging to the Bali Turtle Island Development (BTID) and the other belonging to Pekraman Serangan Village.

Serangan Village (Serangan Island) is a designated or part of a key area in terms of regional development policy. These strategic roles are: (1) As part of the Sarbagita Urban Area's National Strategic Area (KSN). Kuta-Sanur-Nusa Dua and its environs are part of the National Tourism Strategic Area (KSPN); (2) As part of the Sanur Tourism Strategic Area, which is part of the Provincial Strategic Area; (3) Denpasar City has identified Serangan Island as a Strategic Area with a major economic importance in the city or region.

Serangan Island is situated between the "golden triangle" of tourism sites in the Bali Region, including the Sanur, Nusa Dua, and Kuta areas, based on its geographical location. The three tourism zones in Bali are the most developed tourist sites. Serangan tourist village's development can benefit from its strategic location amid the three developed tourism areas, particularly in the development of tourism destinations, industry, and marketing.

I Wayan Sutarja, Secretary of Serangan Pokdarwis, said in an interview that Serangan Village has a lot of tourism potential, which is divided into three segments: marine tourism attractions such as white sandy beaches with calm waves, which can be turned into special interest tours such as fishing and watersports. Local communities that are part of the Serangan fishermen organization also run a fishing cage business.

A prospective culinary tourism attraction is owned by the local Serangan community, who offer seaweed snacks as traditional Serangan souvenirs. Local coastal restaurants have sprouted in Serangan Village, offering traditional Serangan grilled fish cuisine as well as a 
culinary with a beachfront view idea to provide tourists with a more immersive experience.

In an interview, I Nyoman Tura, the head of BUMDA Serangan, stated that the local Serangan community manages 45 restaurant companies.

In addition to marine and culinary tourism, there is a potential cultural tourism destination in the form of Kampung Bugis, which is home to Bugis fisherman who have lived there since the reign of the king. In addition, in Serangan Village, there is the Assyuhada Mosque, which was built in the 17th century and has become a symbol of the Bugis village. There's also the Sakenan Temple, which was erected in the 10th century AD by Mpu Kuturan, who based his design on the Majapahit Kingdom's concept.

\subsection{Tourism Village Management Strategy in Realizing Quality Tourist Destinations}

Serangan Village quickly formed a tourism awareness organization, chaired by I Nyoman Wirata and assisted by I Wayan Sutarja as secretary, after being formally designated as a tourist village by Mayor's Decree no. 188.45/472/HK/2015. Serangan Village also established a BUMDA, which was managed by I Nyoman Tura as chairman and was in charge of managing many tourism attractions in the village.

According to an interview with Mr. I Nyoman Tura (Chairman of BUMDA), BUMDA administration is primarily concerned with managing user fees at each tourist site, such as docks, conservation tourism, and also from tourism fishing organizations. BUMDA is in charge of this retribution, which is used for the community's benefit.

The Tourism Awareness Group serves as a conduit between the community and the Denpasar City Government, expressing community concerns about the services and infrastructure required to build tourist communities in Serangan. The Denpasar City Government is actively involved in improving tourism infrastructure and facilities in Serangan Village, such as widening and repairing the bridge road to Serangan Island, adding toilet facilities to support tourist villages, and constructing crossing piers for tourists to Nusa Penida and Nusa. Lembongan Islands.

POKDARWIS, in collaboration with the Denpasar City Government, plays a dynamism role in encouraging local communities to participate in the development of tourist villages in Serangan, namely by holding skills training and management of tourist attractions, so that management of tourist attractions in Serangan Tourism Village becomes more professional in the future. According to an interview with Dewi Dhyana Putra, A.Par, the Head of Tourism Development for the Denpasar City Tourism Office, many trainings for aiding tourist villages were organized in partnership with tourism associations and several tourism campuses in Bali during 2018 and 2020.

The Serangan Village POKDARWIS approach began to mobilize and motivate local populations to participate actively in the development of Serangan Village tourism sites. Apart from fishing, the fishing organizations began selling fishing tour packages on the high seas and constructed hygienic fishing cages with canteens, where fishing tourism facilities made fishing fans more comfortable and encouraged them to participate in krambah fishing activities. - Krambah in Serangan Village at a fairly affordable cost. This will almost likely result in more jobs and greater revenue for fisherman in Serangan.

Culinary tourism in Serangan Village has also begun to be organized and given a location on the edge of the mangroves in Serangan, allowing tourists to taste traditional Serangan grilled fish cuisine while taking in views of the mangrove woods and the open seas. Of course, this increases the number of tourists visiting Serangan, who, in addition to enjoying beach vistas and marine activities, may also participate in culinary tours.

The management of the tourist village in Serangan is dominated by local people, according to I Wayan Sutarja, Secretary of the Serangan Village POKDARWIS. There is also a private-sector tourism business, namely watersports, although this does not conflict with the tourism business held by the local community. Even existing watersports enterprises and ferry docks give direct support for small businesses owned by the Serangan Village community, where tourists participating in watersport activities shop at local businesses.

This is in line with [9] research, which found that good management of tourist attractions is fully and competently handled by local communities, resulting in these tourist destinations providing significant advantages to local communities. This is also in line with research conducted in Botswana, Africa, by reference [10], who claims that the development of community-based tourist destinations will empower and benefit local communities, particularly in the economic field, so they are constantly striving to improve the quality of their regional tourist destinations, and, at the same time, contribute to the maintenance of existing facilities and infrastructure in particular tourist areas in order to establish high-quality, long-term attractions.

\section{CONCLUSION}

Pokdarwis communicate the aspirations of the local community regarding the facilities and infrastructure needed in the development and management of Serangan Tourism Village through the Serangan Village Tourism Awareness Group, which acts as a mediator 
between the government and the local community. This makes the Denpasar City Government's role as a facilitator in inventorying needs for the tourism village development in Serangan Village considerably easier.

Pokdarwis and Denpasar City Government collaborate and play an active role as facilitators in the development and maintenance of tourist villages in Serangan Village, by providing services and building infrastructure. Pokdarwis and the Denpasar City Government also act as catalysts for community participation in the development of tourist villages in Serangan, namely by holding professional training in skills and management of tourist attractions in collaboration with several tourism associations and tourism campuses in Bali, as well as providing assistance in the management of Serangan Tourism village.

\section{REFERENCES}

[1] H. C. Choi and E. Sirakaya, "Sustainability Indicators For Managing Community Tourism. Tourism Management,” vol. 27, pp. 75-89, 2006.

[2] M. H. U. Dewi, C. Fandeli, and M. Baiquni, "Pengembangan Desa Wisata Berbasis Partisipasi Masyarakat Lokal Di Desa Wisata Jatiluwih Tabanan," Kawistara, vol. 3, no. 2, pp. 117-226, 2013.

[3] D. P. Prasiasa, "Pengembangan Pariwisata Dan Keterlibatan Masyarakat Di Desa Wisata Jatiluwih, Kabupaten Tabanan," Universitas Udayana, 2010.
[4] I. W. Arka, "Pemberdayaan Desa Adat Dlaam Pengembangan Pariwisata Budaya Di Bali: Kasus Desa Wisata Terpadu Penglipuran Bangli," Universitas Udayana, 1999.

[5] I. G. Pitana, Pemberdayaan Dan Hiperdemokrasi Dalam Pembangunan Pariwisata. Denpasar: Pustaka Larasan, 2011.

[6] Mowforth and Munt, Tourism and Sustainability. London: Routledge, 2000.

[7] A. Sucipta, "Strategi Pengembangan Ekowisata Desa Blimbing Kecamatan Pupuan Kabupaten Tabanan," 2010.

[8] K. Antara, "Strategi Pengembangan Wisata Alternatifdi Desa Plaga Kecamatan Petang Kabupaten Badung," Universitas Udayana, 2011.

[9] S. P. Drake, Local Participation in Ecoturism Project, The Nuts and Bolts of Successful Nature Tourism. Canada: CIDA, 1993.

[10] L. S. Sebele, "Community-Based Tourism Ventures, Bene Ts And Challenges: Khama Rhino Sanctuary Trust, Central District, Botswana," Tour. Manag., vol. 31, pp. 136-146, 2010. 